\title{
Plumbogummite group minerals in Lower Devonian placoderm sandstones from Podłazie Hill, Holy Cross Mountains, Poland
}

\author{
Łukasz KRUSZEWSKI ${ }^{1, *}$ and Marek DEC ${ }^{2}$ \\ 1 Polish Academy of Sciences, Institute of Geological Sciences, Twarda 51/55, 00-818 Warszawa, Poland \\ 2 Polish Academy of Sciences, Institute of Paleobiology, Twarda 51/55, 00-818 Warszawa, Poland
}

Kruszewski, Ł., Dec, M., 2018. Plumbogummite group minerals in Lower Devonian placoderm sandstones from Podłazie Hill, Holy Cross Mountains, Poland. Geological Quarterly, 62 (2): 353-360, doi: 10.7306/gq.1410

\begin{abstract}
Samples of Lower Devonian vertebrate-bearing placoderm sandstones collected in a quarry at Podłazie Hill in the Holy Cross Mountains, central Poland, were found to contain numerous white and brownish aggregates of an unknown composition. Powder X-Ray Diffraction study has shown them to comprise plumbogummite group minerals (PGM). Gorceixite is most common, usually forming compact/porous aggregates. They are either found in voids within the quartz-rich zircon-, muscovite- and biotite-bearing matrix, or as a complete replacement after bone remnants. Goyazite aggregates are similar but rarer. Strontian crandallite is found as tiny zoned crystals closely associated with compact gorceixite (in the sandstone matrix) or as cores of fine-grained gorceixite aggregates (within the bones). All of the PGMs are enriched in Ce and La with two analyses marginally within the compositional field of florencite-(Ce). Ca enrichment, elevated $\mathrm{F}$ content and abundance of goyazite within the bone replacement suggest the primary bone apatite group as the source of these elements. Tuffites and claystones associated with the sandstones are probably the source of $\mathrm{Ba}$ and $\mathrm{Sr}$, while $\mathrm{Pb}$ is possibly derived from local $\mathrm{De}$ vonian mineralisation.
\end{abstract}

Key words: plumbogummite group minerals, REE enrichment, gorceixite, goyazite, crandallite, bone replacement.

\section{INTRODUCTION}

Plumbogummite group minerals (PGM) are phosphate representatives of the alunite supergroup (AS). Of the sixteen PGM members currently known, the most common are crandallite, $\mathrm{CaAl}_{3}\left(\mathrm{PO}_{4}\right)\left(\mathrm{PO}_{3} \mathrm{OH}\right)(\mathrm{OH})_{6}$, its $\mathrm{Ba}$ analogue gorceixite, and goyazite the $\mathrm{Sr}$ analogue. All three species typically occur within carbonatites and various sedimentary rocks. Gorceixite and goyazite may in addition be of a hydrothermal origin. Crandallite and goyazite are sometimes found within granitic pegmatites, while gorceixite may also exist in greisens and soils. A sandstone-hosted occurrence of PGMs was reported by Bain (1970). In Poland, gorceixite is reported in a hydrothermal fluorite-baryte deposit at Stanisławów-Gorce (Kowalski and Śmietańska, 1982). Muszyński and Wyszomirski (1982) mentioned the presence of some PGMs in "Graupen" tonsteins of the Lublin Coal Basin.

Other PGM members are more scarcely distributed. The archetypal plumbogummite member is found in weathering zones of $\mathrm{Pb}$ ore deposits as a moderately rare secondary mineral. Florencite-(Ce), although much rarer, may exist in various rocks including bauxites (and other sedimentary rocks), carbo-

\footnotetext{
* Corresponding author, e-mail: Ikruszewski@twarda.pan.pl Received: December 14, 2017; accepted: January 19, 2017; first published online: May 8, 2018
}

natites, and gabbros, while being authigenic in shales and sandstones (Anthony et al., 2000).

In recent years AS minerals have been extensively studied by environmental scientists as they may crystallize from acidic mine waters thus immobilizing some toxic metals (Bigham and Nordstrom, 2000; Kolitsch and Pring, 2001; Dzikowski et al., 2006). Indeed, the PGM analysed by Bain (1970) show elevated amounts of $\mathrm{Ni}, \mathrm{TI}, \mathrm{Cr}$, Cu and $\mathrm{V}$, being also enriched in $\mathrm{Ag}, \mathrm{Zr}$ and Ti. They are also important carriers of rare earth elements (REE; e.g., Bayliss et al., 2010). Another important aspect of AS is their occurence on Mars (e.g., Klingelhöfer et al., 2004). Association of the PGM with bone remnants is a relatively rarely described phenomenon, with a prominent exception of Brazilian gorceixite described by Coutinho et al. (1999). This paper concentrates mainly on the crystal chemistry of PGM found in Lower Devonian age bone-bearing placoderm sandstones of Podłazie Hill, Holy Cross Mountains, central Poland.

\section{GEOLOGICAL SETTING}

Szrek et al. (2017) described in detail the geological setting of a quarry in the Podłazie Hill, where both the fossil bones and PGM were found. The site location shown in Figure 1 lies within the Kielce Region. Lower Devonian sandstones and mudstones dominate in the quarry, with some siltstone, claystone, and conglomerate intercalations present. Quartzitic placoderm sandstones are considered to represent shallow-marine, transitional, paralic origin. They are occasionally found intercalated 


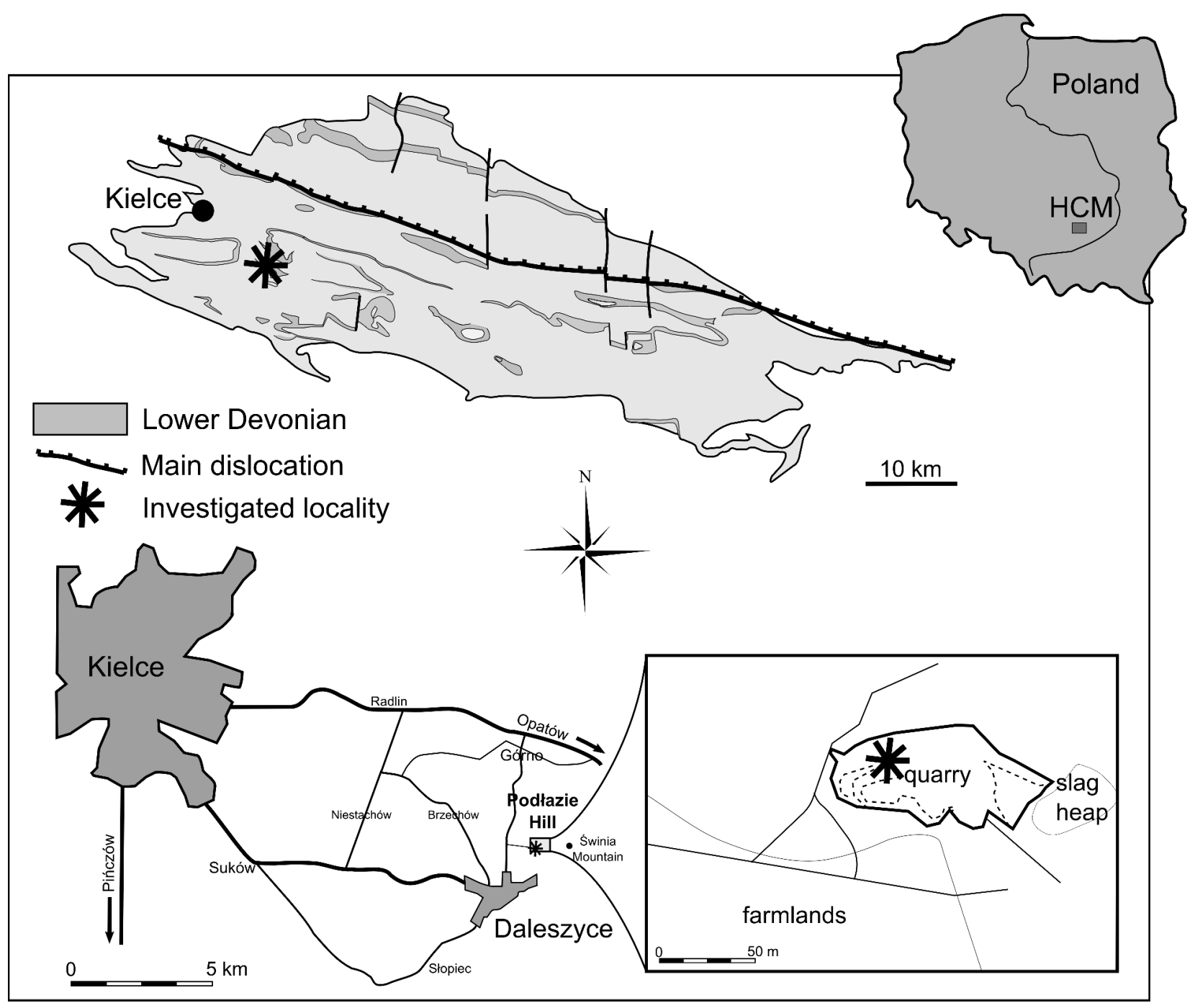

Fig. 1. Location of the Podłazie Quarry

The map is taken from the paper of Szrek et al. (2017); HCM - Holy Cross Mountains

with tuffaceous claystones and are overlain by pyrite- and siderite-bearing claystones, dolomites, and limestones. Concentrations of bone remains and associated very coarse-grained sandstones in the lower part of the sandstone-bearing layer is interpreted as storm-induced. Consequently the fossil concentrations are composed of broken bones, plater, spines and scales. Replacement of the bones by white to brownish, porous material is clearly evident. Although the bone structure is perfectly preserved and its histological features easily observed, some of the bone remains are suggested by Szrek et al. (2017) to be once subjected to hydrothermal alteration.

\section{METHODS}

Identification of the PGM aggregates was undertaken using Powder X-Ray Diffraction (PXRD). Powdered sample, originally ca. $0.5 \mathrm{~cm}$ in diameter, was placed in a standard perforation plastic holder in a Bruker axs D8 ADVANCE diffractometer equipped with superfast linear position-sensitive detector (LPSD), VÅNTEC-1 model, and CoK $\alpha$ radiation lamp (Ni k $\beta$ filter used). The apparatus was located in the X-Ray Diffraction
Laboratory, Institute of Geological Sciences, Polish Academy of Sciences (Warsaw). The sample was scanned using $0.02^{\circ} 2 \theta$ increment and $1 \mathrm{~s} /$ step counting time (scintillation counter scale, equal to $416 \mathrm{~s}$ of the LPSD scale), in the $3-80^{\circ} 2 \theta$ range. Unit cell parameters of three observed PGM representatives (i.e., $2.940 \AA$ reflection ascribed to crandallite, $2.958 \AA$ ascribed to goyazite, and $3.008 \AA$ attributed to gorceixite), were calculated using the Rietveld method (Rietveld, 1967) implemented in TOPAS v. 3.0 software. The software is incompatible with LPSD detectors, i.e., the Receiving Slit (RS) parameter is physically different from that corresponding to a point detector, and it can not be applied directly. Thus, a method suggested by David Bish (pers. comm. via the Rietveld Mailing List), was applied:

- $\mathrm{LaB}_{6}$ standard (NIST SRM 660a) with known unit cell parameter and mean crystallite size was scanned first;

- the obtained spectrum was refined with the above structural parameters fixed, with an additional convolution added in the instrument section being refined;

- various function types and corresponding $2 \theta$ dependencies were checked, and the one with value larger than the corresponding error (esd), i.e., the physically meaningful one, was chosen as a parameter imitating the RS; 
- the obtained value was then fixed, and used (as a profile geometry description) to calculate unit cell parameters of $\mathrm{LaB}_{6}$ and other standards (including Si);

- the obtained values were almost identical to the certified ones, thus confirming the applicability of the convolution to relevant refinement;

- unit cell parameters of the PGM were calculated using the above value, with Start $X$ and Finish $X$ parameters constrained to middle angular range in which reflection positions are least dependent on instrument-related shift.

Chemical composition, crystal habit and spatial dependence of the PGM and the associated minerals was studied using a carbon-coated polished thin section placed in a CAMECA SX100 Scanning Electron Microscope (SEM) located in the Inter-Institute Laboratory of Microanalysis of Minerals and Synthetic Materials, Institute of Geochemistry, Mineralogy and Petrology, Faculty of Geology, University of Warsaw, Poland. Spot chemical microarea analysis was conducted by Electron Probe Microanalysis (EPMA) using Wavelength Dispersive Spectroscopy (WDS).

The beam current was low - $6 \mathrm{nA}$ - to lower beam-induced sample dehydration; the acceleration voltage was $15 \mathrm{kV}$. The following standards were used: orthoclase (for $\mathrm{Al}$ ), $\mathrm{SrTiO}_{3}$ (for $\mathrm{Sr}$ ), synthetic fluorapatite (for $F$ and $P$ ), GaAs (for As), YAG $\left(\mathrm{Y}_{3} \mathrm{Al}_{5} \mathrm{O}_{12}\right.$ garnet, for $\mathrm{Y}$ ), wollastonite (for $\mathrm{Si}$ and $\mathrm{Ca}$ ), REE-bearing glass no. 1 (for $\mathrm{Pr}$ ) and no. 3 (for $\mathrm{Sm}$ ), $\mathrm{NdGaO}_{3}$ (for $\mathrm{Nd}$ ), $\mathrm{Fe}_{2} \mathrm{O}_{3}$ (for $\mathrm{Fe}$ ), GGG $\left(\mathrm{Gd}_{3} \mathrm{Ga}_{5} \mathrm{O}_{12}\right.$ garnet, for $\mathrm{Gd}$ ), $\mathrm{ErP}_{5} \mathrm{O}_{14}$ (for $\mathrm{Er}$ ), $\mathrm{YbP}_{5} \mathrm{O}_{14}$ (for $\mathrm{Yb}$ ), $\mathrm{HoP}_{5} \mathrm{O}_{14}$ (for $\mathrm{Ho}$ ), barite (for $\mathrm{Ba}$ and $\mathrm{S}$ ), $\mathrm{PbS}$ (for $\mathrm{Pb}$ ), tugtupite (for $\mathrm{Cl}$ ), $\mathrm{LaB}_{6}$ (for $\mathrm{La}$ ), $\mathrm{CeP}_{5} \mathrm{O}_{14}$ (for $\mathrm{Ce}$ ), vorlanite (for $\mathrm{U}$ ), and $\mathrm{ThO}_{2}$ (for $\mathrm{Th}$ ). $\mathrm{Na}, \mathrm{Mg}, \mathrm{K}, \mathrm{Ti}, \mathrm{Mn}, \mathrm{Cu}$ and $\mathrm{Zn}$, were not observed in the EDS spectra. These elements were quantified during trial standardized EDS analyses (JEOL JSM-6380LA scanning electron microscope, Laboratory of Basic Analyses, Institute of Geological Sciences, Polish Academy of Sciences, Warsaw). However, these quantifications are of a limited importance as many line interferences are possible and cannot be fully subtracted with the EDS system used.

\section{MINERAL HABIT AND CRYSTAL CHEMISTRY}

The PGM occur both in small voids within the sandstone matrix, and as a direct replacement of bone material, with either spongy or laminar bone texture preserved to some extent. They may also form long veinlets among the sandstone matrix (Fig. 2). Three types of habits are recognized in the microprobe images (Fig. 3):

- compact/porous, finely-crystalline aggregates, most common (Fig. 3A, B), found in the sandstone voids and designated "type I";

- rare, complex-zoned larger crystals, usually intergrown, found within the sandstone matrix (Fig. 3C), described here as "type II";

- zoned crystals disseminated within the bone matrix, in thin veinlets or, at the margins of type I aggregates, herein referred to as "type III" (Fig. 3D).

The bone matrix - "type IV" - represents complete PGM pseudomorphs after bioapatite: no original apatite group species have been identified. The type I PGM may occasionally, in

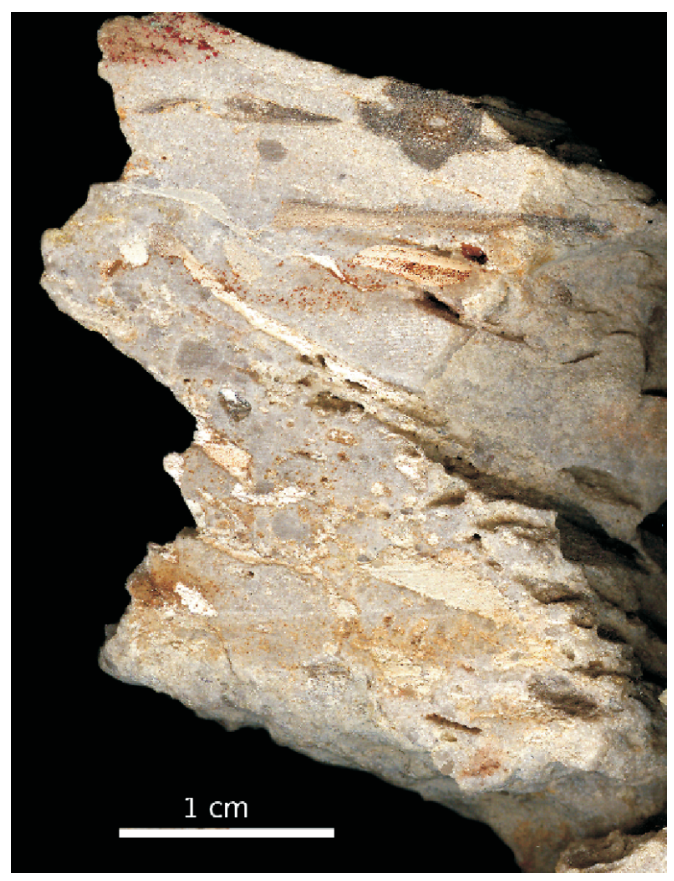

Fig. 2. General view of a fragment of the placoderm sandstone

The white veinlet-like material is plumbogummite group replacing bone remnants

Backscattered electron (BSE) mode, show darker cores enriched in $\mathrm{Ca}$ and compositionally corresponding to type III. Types I and IV compositionally fit to gorceixite (Appendix 1*; Fig. 4); the latter type is slightly more Ce-enriched but plots close to datapoints for analogous bone-replacement gorceixite of Coutinho et al. (1999). Rarely observed coarsely-crystalline equivalents of the type I will hereafter be referred to as "type II". It is also gorceixite, but occasionally (two of the whole 67 EPMA analyses) may be florencite-(Ce) (Fig. 5). The latter figure also shows our PGM to be usually much more enriched in REE when compared to those of Coutinho et al. (1999). Type III is almost exclusively goyazite, although some crystals' analyses recast to crandallite-dominant composition. Due to coarse-crystalline nature, type II and especially type III seem to represent a secondary generation of the PGM under scope. Some Sr-rich, REE-low and Si-free crystals found within more compact bone stand for the "type Illa". Empirical formulas corresponding to the above types are given below:

- type I $(n=11)$ :

$\left(\mathrm{Ba}_{0.64} \mathrm{Ca}_{0.21} \mathrm{Ce}_{0.20} \mathrm{Sr}_{0.04} \mathrm{~Pb}_{0.02}\right)_{\Sigma 1.11} \mathrm{Al}_{2.87}\left(\mathrm{PO}_{4}\right)_{1.00}\left[\left(\mathrm{P}_{0.86} \mathrm{Si}_{0.13}\right)\right.$ $\left.{ }_{\Sigma 0.99} \mathrm{O}_{2.97}(\mathrm{OH})_{0.99}\right]\left[(\mathrm{OH})_{5.61} \mathrm{~F}_{0.31}\left(\mathrm{H}_{2} \mathrm{O}\right)_{0.09}\right]_{\Sigma 6.01}$, corresponding to $\mathrm{Gcx}_{57} \mathrm{Cnd}_{19} \mathrm{Flr}_{18} \mathrm{Goy}_{3} \mathrm{Pbg}_{2}$, where $\mathrm{Gcx}=$ gorceixite, Cnd $=$ crandallite, $\mathrm{Flr}=$ sum of florencite-(Ce) and florencite-(La), Goy = goyazite, and Pbg = plumbogummite end-members:

- type II $(n=8)$ :

$\left(\mathrm{Ba}_{0.40} \mathrm{Ce}_{0.23} \mathrm{Ca}_{0.15} \mathrm{Sr}_{0.13} \mathrm{La}_{0.06} \mathrm{~Pb}_{0.04}\right)_{\Sigma 1.01} \mathrm{Al}_{2.94}\left(\mathrm{PO}_{4}\right)_{1.00}\left[\left(\mathrm{P}_{0.85}\right.\right.$ $\left.\left.\mathrm{S}_{0.10} \mathrm{Si}_{0.06}\right)_{\Sigma 1.01} \mathrm{O}_{3.03}(\mathrm{OH})_{1.01}\right]\left[(\mathrm{OH})_{5.96} \mathrm{~F}_{0.19}\right]_{\Sigma 6.15} 0.82 \mathrm{H}_{2} \mathrm{O}$, corresponding to $\mathrm{GcX}_{36} \mathrm{Flr}_{28} \mathrm{Goy}_{14} \mathrm{Cnd}_{18} \mathrm{Pbg}_{3}$; 

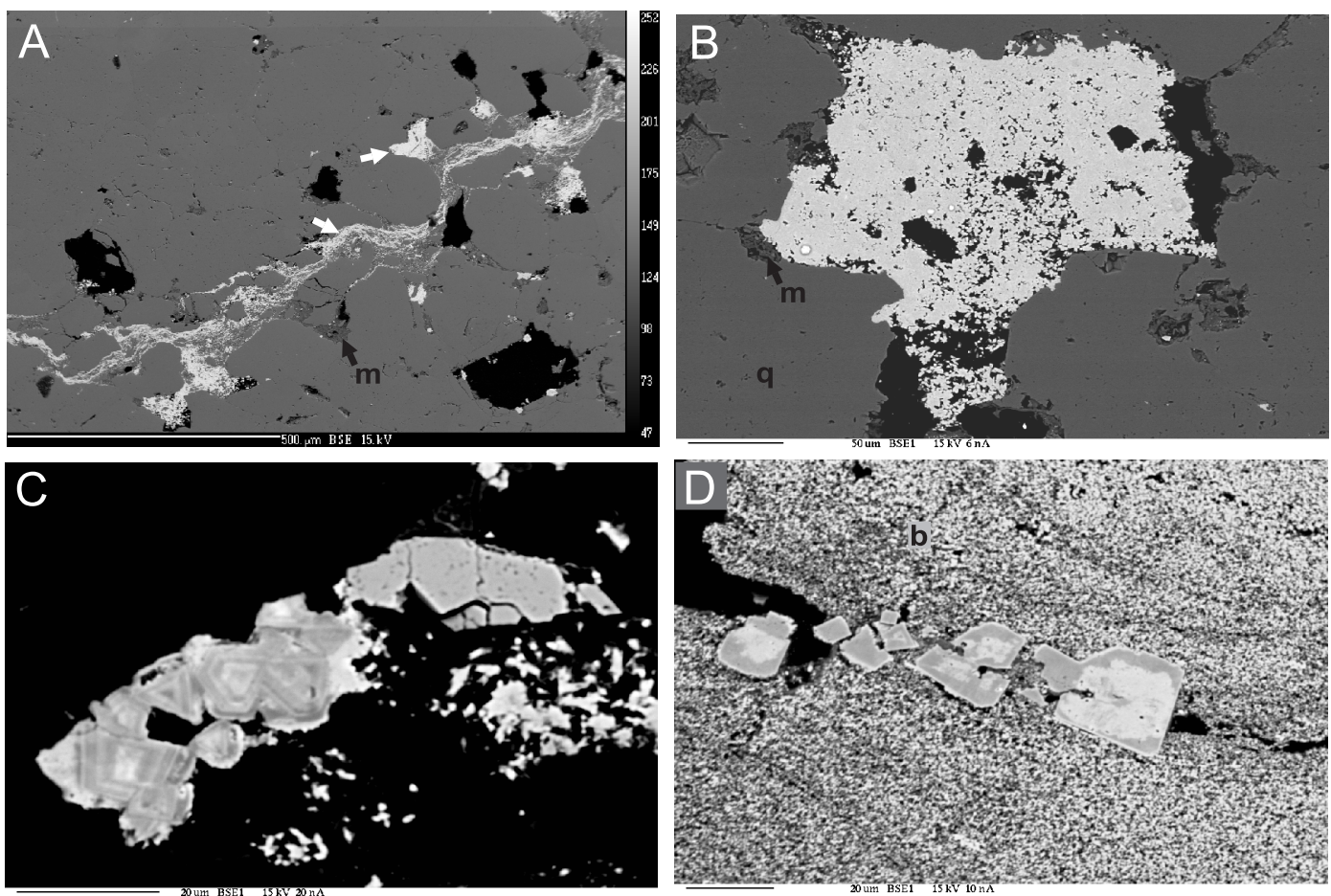

Fig. 3. BSE (back-scatter electron) images of the plumbogummite group aggregates and crystals

A - veinlet-forming and compact/porous aggregates of mainly gorceixite among quartz-muscovite matrix of the plakoderm sandstone (type I); B - porous gorceixite aggregate magnified (type I; bright rounded objects are post-analytical spots); C - complex-zoned crystals within the sandstone matrix (type II); D - zoned crystals among the bone replacement matter (type III); b - bone replacement matter, $\mathrm{m}$ - muscovite (slightly Ba-enriched), q - quartz

- type III $(n=14)$ :

$\left(\mathrm{Sr}_{0.40} \mathrm{Ca}_{0.28} \mathrm{Ba}_{0.19} \mathrm{Ce}_{0.13} \mathrm{La}_{0.04} \mathrm{~Pb}_{0.03}\right)_{\Sigma 1.07} \mathrm{Al}_{2.91}\left(\mathrm{PO}_{4}\right)_{1.00}\left[\left(\mathrm{P}_{0.85}\right.\right.$ $\left.\left.\mathrm{S}_{0.17} \mathrm{Si}_{0.01}\right)_{\Sigma 1.03} \mathrm{O}_{3.09}(\mathrm{OH})_{1.03}\right]\left[(\mathrm{OH})_{6.10} \mathrm{~F}_{0.04}\right]_{\Sigma 6.14} 0.45 \mathrm{H}_{2} \mathrm{O}$, corresponding to $\mathrm{Goy}_{38} \mathrm{Cnd}_{27} \mathrm{Gcx}_{17} \mathrm{Flr}_{16} \mathrm{Pbg}_{2}$;

- type Illa $(n=3)$ :

$\left(\mathrm{Sr}_{0.73} \mathrm{Ca}_{0.23} \mathrm{Ce}_{0.05} \mathrm{La}_{0.03} \mathrm{Ba}_{0.02} \mathrm{~Pb}_{0.01}\right)_{\Sigma 1.07} \mathrm{Al}_{2.81}\left(\mathrm{PO}_{4}\right)_{1.00}\left[\left(\mathrm{P}_{0.85}\right.\right.$ $\left.\left.\mathrm{S}_{0.21}\right)_{\Sigma 1.06} \mathrm{O}_{3.18}(\mathrm{OH})_{1.06}\right]\left[(\mathrm{OH})_{5.67}\left(\mathrm{H}_{2} \mathrm{O}\right)_{0.26} \mathrm{~F}_{0.07}\right]_{\Sigma 5.98} 0.84 \mathrm{H}_{2} \mathrm{O}$, corresponding to $\mathrm{Goy}_{68} \mathrm{Cnd}_{22} \mathrm{Flr}_{8} \mathrm{Pbg}_{1} \mathrm{Gcx}_{2}$;

- type IV $(n=11)$ :

$\left(\mathrm{Ba}_{0.74} \mathrm{Ce}_{0.24} \mathrm{Ca}_{0.16} \mathrm{Sr}_{0.03} \mathrm{~Pb}_{0.01}\right)_{\Sigma 1.18} \mathrm{Al}_{2.91}\left(\mathrm{PO}_{4}\right)_{1.00}\left[\mathrm{P}_{0.90} \mathrm{O}_{2.70}\right.$ $\left.(\mathrm{OH})_{0.90}\right]\left[(\mathrm{OH})_{4.88} \mathrm{~F}_{0.29}\right]_{55.05}$, corresponding to $\mathrm{GcX}_{62} \mathrm{Flr}_{21}$ $\mathrm{Cnd}_{14} \mathrm{Goy}_{3} \mathrm{Pbg}_{1}$;

As can be seen above, the type IV formula shows 1.36 apfu (atoms per formula unit) excess, triggering a charge unbalance. The cause of such excess may be a possible intergrowth with a yet unrecognized bioapatite precursor. Due to the charge unbalance a set of additional analyses using a scanning beam mode was conducted. The empirical formula corresponding to this set is $(n=4)$ : $\left(\mathrm{Ba}_{0.67} \mathrm{Ce}_{0.23} \mathrm{Ca}_{0.19} \mathrm{Sr}_{0.04}\right.$ $\left.\mathrm{Pb}_{0.04}\right)_{\Sigma 1.17} \mathrm{Al}_{2.89}\left(\mathrm{PO}_{4}\right)_{1.00}\left[\left(\mathrm{P}_{0.89} \mathrm{~S}_{0.03} \mathrm{Si}_{0.02}\right)_{\Sigma 0.94} \mathrm{O}_{2.82}(\mathrm{OH})_{0.94}\right]$ $\left[(\mathrm{OH})_{4.41} \mathrm{~F}_{0.28}\right]_{\Sigma 4.69}$; thus, the result is similar. However, WDS analysis of hydrates/hydrous minerals may blur the real content of light elements compared to EDS analysis, as shown by Kruszewski (2013).

It should be stated, that all the above formulas represent whole analytical ranges of the particular types and thus do not show the intra-type compositional variability. Although not a case with type IV, some of the remaining types include various cases of end-member domination. This is especially true in the case of the type II: 6 of 8 corresponding analyses recast to gorceixite, but the two remaining ones to a compositionally

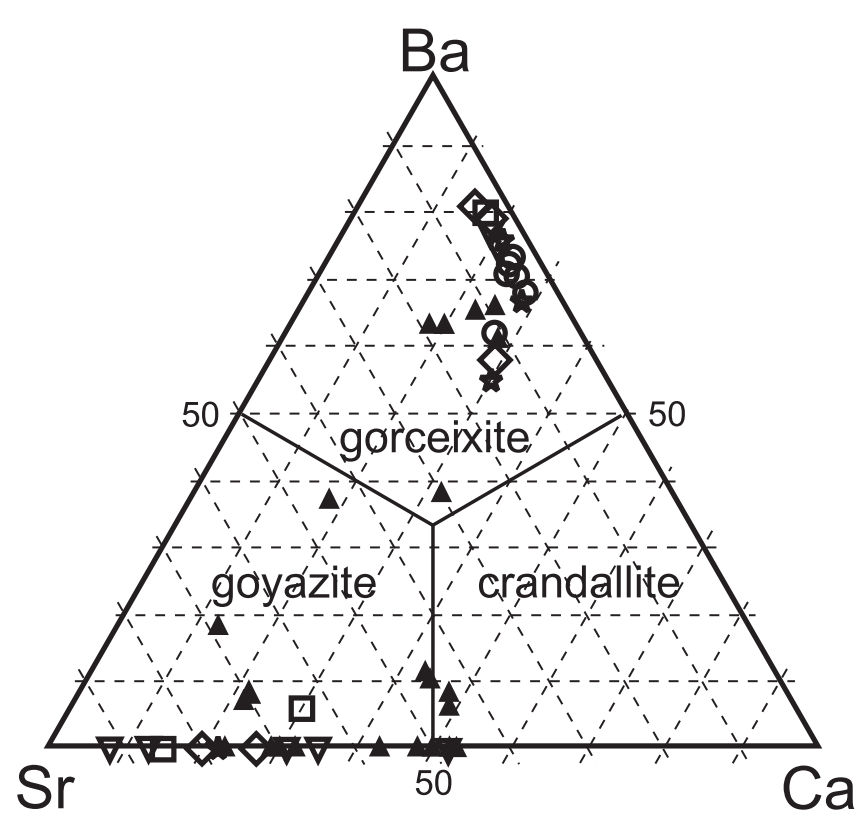

Fig. 4. Barycentrical representation of the composition of the Podłazie plumbogummite group phases in the Ba-Sr-Ca system

Circles - type I aggregates; stars - type II coarse crystals; upward filled triangles - crystals within the bone replacement matter; squares - crystals within compact bone-replacement zones; diamonds - bone replacement matter; downward open triangles - bone zones (scanning beam analysis); filled small circles - data from Coutinho et al. (1999); most of the points plot to within either gorceixite or goyazite fields 
completely different phase - florencite-(Ce). The mean compositions are as follows:

- $\left(\mathrm{Ba}_{0.53} \mathrm{Ca}_{0.23} \mathrm{Ce}_{0.21} \mathrm{Sr}_{0.06} \mathrm{~Pb}_{0.05} \mathrm{La}_{0.01}\right)_{\Sigma 1.09} \mathrm{Al}_{2.90}\left(\mathrm{PO}_{4}\right)_{1.00}$ $\left[\left(\mathrm{P}_{0.88} \mathrm{~S}_{0.05} \mathrm{Si}_{0.08}\right)_{\Sigma 1.01} \mathrm{O}_{3.03}(\mathrm{OH})_{1.01}\right]\left[(\mathrm{OH})_{5.79} \mathrm{~F}_{0.26}\right]_{\Sigma 6.05} 0.27$ $\mathrm{H}_{2} \mathrm{O}(n=6)$, corresponding to $\mathrm{GcX}_{48} \mathrm{Flr}_{21} \mathrm{Cnd}_{21} \mathrm{Goy}_{6} \mathrm{Pbg}_{5}$ for gorceixite, and

- $\left[\left(\mathrm{Ce}_{0.28} \mathrm{La}_{0.18}\right)_{\Sigma 0.46} \mathrm{Sr}_{0.35} \mathrm{Ca}_{0.09}\right]_{\Sigma 0.90} \mathrm{Al}_{3.03}\left(\mathrm{PO}_{4}\right)_{1.00}$ $\left.\left[\mathrm{P}_{0.78} \mathrm{~S}_{0.25} \mathrm{Si}_{0.03}\right]_{\Sigma 1.06} \mathrm{O}_{3.18}(\mathrm{OH})_{1.06}\right](\mathrm{OH})_{6.45} 2.47 \mathrm{H}_{2} \mathrm{O}(n=$ 2), corresponding to $\mathrm{Flr}_{51} \mathrm{Goy}_{39} \mathrm{Cnd}_{10}$ for florencite-(Ce)

15 analyses of the type III PGM fit a goyazite-dominant composition, 7 to gorceixite and 3 to crandallite. The latter phase was not found in any other spots analysed. The following empirical formulas describe the full chemical variation of the type-III aggregates:

- $\left(\mathrm{Sr}_{0.54} \mathrm{Ca}_{0.28} \mathrm{Ce}_{0.10} \mathrm{Ba}_{0.06} \mathrm{La}_{0.05} \mathrm{~Pb}_{0.02}\right)_{0.99} \mathrm{Al}_{2.91}\left(\mathrm{PO}_{4}\right)_{1.00}$ $\left[\left(\mathrm{P}_{0.84} \mathrm{~S}_{0.20} \mathrm{Si}_{0.01}\right)_{\Sigma 1.05} \mathrm{O}_{3.15}(\mathrm{OH})_{1.05}\right]\left[(\mathrm{OH})_{6.04} \mathrm{~F}_{0.01}\right]_{\Sigma 6.05} 0.76$ $\mathrm{H}_{2} \mathrm{O}$, corresponding to $\mathrm{Goy}_{52} \mathrm{Cnd}_{27} \mathrm{Flr}_{14} \mathrm{Gcx}_{5} \mathrm{Pbg}_{2}$ for goyazite;

- $\left[\mathrm{Ba}_{0.53} \mathrm{Ca}_{0.21} \mathrm{Ce}_{0.19} \mathrm{Sr}_{0.07} \mathrm{~Pb}_{0.05} \mathrm{La}_{0.01}\right]_{\Sigma 1.06} \mathrm{Al}_{2.89}\left(\mathrm{PO}_{4}\right)_{1.00}$ $\left[\left(\mathrm{P}_{0.87} \mathrm{~S}_{0.10} \mathrm{Si}_{0.02}\right)_{\Sigma 0.99} \mathrm{O}_{2.97}(\mathrm{OH})_{0.99}\right]\left[(\mathrm{OH})_{5.14} \mathrm{~F}_{0.12}\right]_{\Sigma 5.26}$, corresponding to $\mathrm{Gcx}_{47} \mathrm{Goy}_{11} \mathrm{Cnd}_{19} \mathrm{Flr}_{18} \mathrm{Pbg}_{5}$ for gorceixite, and

- $\left(\mathrm{Ca}_{0.43} \mathrm{Sr}_{0.39} \mathrm{Ce}_{0.11} \mathrm{Sr}_{0.06} \mathrm{La}_{0.05} \mathrm{Ba}_{0.03} \mathrm{~Pb}_{0.01}\right)_{\Sigma 1.08} \mathrm{Al}_{2.92}\left(\mathrm{PO}_{4}\right)_{1.00}$ $\left[\left(\mathrm{P}_{0.85} \mathrm{~S}_{0.19} \mathrm{Si}_{0.02}\right)_{\Sigma 1.06} \mathrm{O}_{3.18}(\mathrm{OH})_{1.06}\right](\mathrm{OH})_{6.13} 1.06 \mathrm{H}_{2} \mathrm{O}$, corresponding to $\mathrm{Cnd}_{42} \mathrm{Goy}_{38} \mathrm{Cnd}_{21} \mathrm{Flr}_{16}$ for crandallite

The above formulas show that, at least in the case of the type-III PGM, Ba has an affinity with $\mathrm{Ce}$ and $\mathrm{F}$, while $\mathrm{Sr}$ more readily coexists with $\mathrm{Ca}$ and $\mathrm{La}$. Also, many type-III goyazite analyses reveal a total absence of $\mathrm{Ba}$. $\mathrm{Pb}$ seems to be more readily concentrated in gorceixite-dominant compositions, likely due to the similarity of its ionic radius to that of $\mathrm{Ba}$. The type-III gorceixite may in addition be divided according to its $\mathrm{Sr}$ and $\mathrm{F}$ enrichment, which varies independently. Its empirical formula still remains slightly unbalanced.

The $\mathrm{BaO}$ content is very variable among the whole PGM series. The mean content $(n=67)$ is $11.7 \mathrm{wt} . \%$, with $0.0 \mathrm{wt} . \%$ in most goyazite crystals found within the bone material, and up to

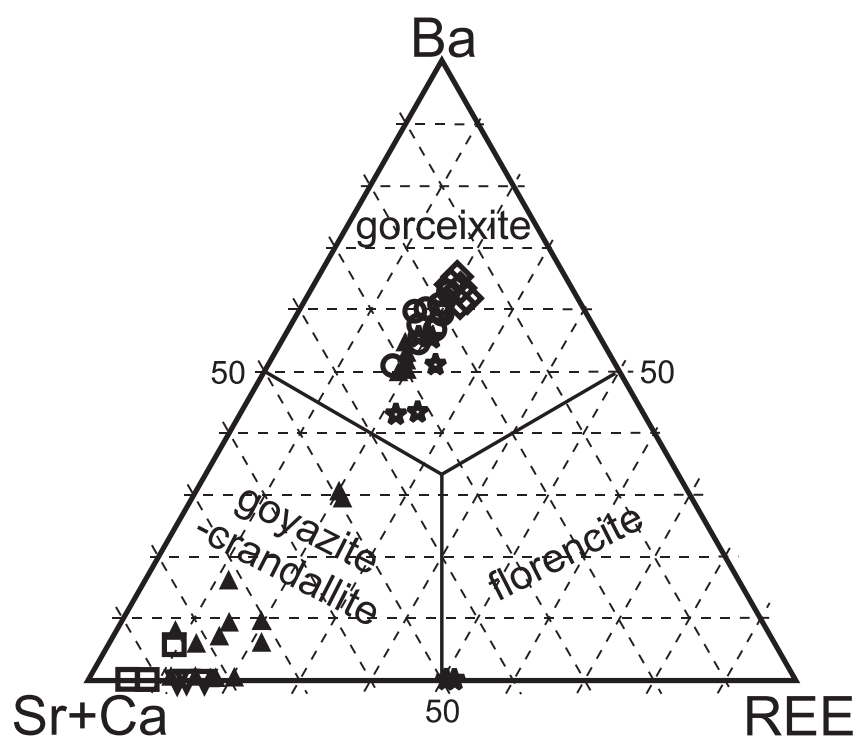

Fig. 5. Barycentrical representation of the composition of the Podłazie plumbogummite group phases in the $\mathrm{Ba}-(\mathrm{Sr}+\mathrm{Ca})$-REE system

For explanations see Figure 4; florencite group compositions are very rarely represented among the material studied

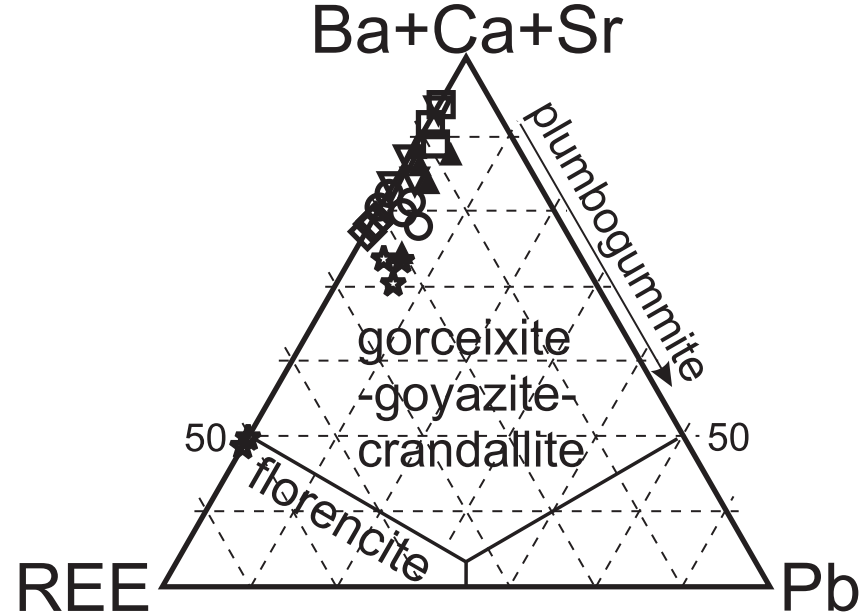

Fig. 6. Barycentrical representation of the composition of the Podłazie plumbogummite group in the (alkaline metal)-REE-Pb system

For explanations see Figure 4; plumbogummite-dominant compositions are absent here

23.6 wt.\% observed in spongy bone matter. The mean content in whole-series gorceixite $(n=39)$ is $19.3 \mathrm{wt}$. \%. Mean BaO content in goyazite $(n=21)$ and crandallite $(n=5)$ is 1.3 and $0.8 \mathrm{wt} . \%$, respectively.

The $\mathrm{SrO}$ content is also variable, with a mean of $5.6 \mathrm{wt} . \%$ and minimum of $0.5 \mathrm{wt} . \%$ for finely-crystalline extra-bone PGM and a maximum of 18.3 wt.\% within coarse crystals in more compact bone matter. Some zones of the the spongy bone matter are also low in Sr. Mean oxide contents for goyazite, gorceixite, and crandallite, are $12.4,1.1$, and $8.6 \mathrm{wt} . \%$, respectively.

The proportion of $\mathrm{Ca}$ is much less variable when compared to its heavier group counterparts. The whole-series, oxide-based mean, is $2.6 \mathrm{wt} . \%$, spanning from $0.99 \mathrm{wt}$ \% (extra-bone coarse crystals) to 5.5 wt. $\%$ (intra-bone coarse crystals). When juxtaposing apfu $\mathrm{Ba}$ versus $\mathrm{Ca}+\mathrm{Sr}$, the datapoints order to give a rather clear negative correlation $\left(r^{2}=0.91\right)$. This seems to connect the types I and IV (gorceixite) clearly placing them against the types III and IIla, which are very Sr-rich but low in or devoid of Ba.

Non-zero values are quite often observed for lead. The mean $\mathrm{PbO}$ content is $\sim 1.0$ wt.\%, with maximum of $3.2 \mathrm{wt} . \%$ found in extra-bone coarse crystals (gorceixite). Zero values concern some zones of the bone matter. Nevertheless, the plumbogummite end-member is never dominant among the material under scope (Fig. 6).

REE are present in all the measured areas and points. The lowest values, $\sim 1.2$ wt. $\% \mathrm{Ce}_{2} \mathrm{O}_{3}$, occur within the bone replacement material (both the spongy and more compact parts). The intra-bone coarse gorceixite crystals contain 8.1 wt. $\% \mathrm{Ce}_{2} \mathrm{O}_{3}$ on average. The highest concentration is found, as expected, in florencite-(Ce), being $9.1 \mathrm{wt} . \%$. If one takes all of the gorceixite analyses, then the corresponding mean is slightly lower: 7.0 wt.\%. Goyazite is much less Ce-enriched, with a mean of 3.1 wt.\%; crandallite seems to be a little bit more cerian, the content being $3.8 \mathrm{wt}$. \% on average. There is a possible negative correlation between $\mathrm{Ce}$ and $\mathrm{Sr}\left(r^{2}=0.79\right)$ and a positive one in the Ce-Ba system $\left(r^{2}=0.66\right)$, but these trends are only observed when plotting the whole datapoints. Relation of $\mathrm{Ce}$ to the alkaline earth metals is better expressed using the $\mathrm{Ce} v s .(\mathrm{Sr}+\mathrm{Ca})$ system, where a clear negative trend with $r^{2}$ being 0.87 . The negative Ce-Sr correlation is not seen in case of the types I and 
IV, but is clearly expressed for the type III, with $r^{2}$ equal to 0.83 . The corresponding Ce-Ba correlation, positive, gives $r^{2}=0.79$. For the latter type, Ce also seems to be somewhat negatively correlated with the calculated $\mathrm{H}_{2} \mathrm{O}$ content $\left(r^{2}=0.65\right)$. When REE are plotted against total alkaline earth metals, a cluser is formed $\left(r^{2}=0.41\right)$.

Fluorine is not always present in the Podłazie PGM, with zero values concerning both the bone replacement matter, most of the secondary intra-bone crystals, and some coarse crystals within the sandstone. Spongy bone matter contains average amounts. The maximum amount of $0.9 \mathrm{wt} \%$ was obtained for finely-crystalline gorceixite (sandstone matrix). The mean for the whole gorceixite range is $0.6 \mathrm{wt} . \%$, and for goyazite just 0.1 wt. $\%$ (0.04 wt. $\%$ for the intra-bone crystals), while crandallite and florencite-(Ce) are fluorine-free. A possible, though not very clear, positive correlation between apfu $\mathrm{F}$ and apfu $\mathrm{Si}$ is observed for some datapoints. The calculated water content is always largest in gorceixite; the whole-analysis mean is $13.5 \mathrm{wt} . \%$, while the average amounts for gorceixite, goyazite and crandallite are $11.2,16.1$ and 17.9 wt.\%, respectively.

Four compositional trends can be deduced from Figure 4. The first one concerns exclusively the type I aggregates and may be described by a vector < $\mathrm{Goy}_{8-19}, \mathrm{Cnd}_{35-18}, \mathrm{Gcx}_{66-62}>$, corresponding to a coupled substitution given as $\mathrm{SrCaBa}_{-2}$ compositional vector in the notation of Burt (1991). The second one is based on the type III and type IIla datapoints and may describe element migration between these two types. It is described either via a vector $<$ Goy $_{92-47}, \mathrm{Cnd}_{8-53}>(\mathrm{Gcx} \approx \mathrm{const} \approx 0)$ or $\mathrm{BaSr}_{-1}$ substitution. The remaining 2 trends are only theoretical, as they are built basing on datapoints corresponding to both bone- and sandstone-located analysis spots. The vectors illustrative of these trends are:

- $<\mathrm{GcX}_{81-67}, \mathrm{Cnd}_{15-29}>(\mathrm{Goy} \approx \mathrm{const} \approx 4)$, corresponding to

$\mathrm{BaCa}_{-1}$ substitution;

- $<\mathrm{Gcx}_{62-54}, \mathrm{Goy}_{11-15}>(\mathrm{Cnd} \approx \mathrm{const} \approx 28)$, corresponding to

$\mathrm{BaSr}_{-1}$ substitution

\section{CRYSTALLOGRAPHY}

Three PGM representatives were identified in the PXRD sample. Gorceixite, which in this case (the PXRD sample was likely derived from a goyazite-rich zone) is not dominant at 13(9) wt.\% calculated content, has the following unit cell parameters: $a=6.996(10), c=17.074(27)$. The corresponding values for crandallite and goyazite are: $66(2) w t . \%, a=6.989(5), c=$ 16.191(9); 18(2) wt.\%, $a=6.976(9), c=16.585(23)$. The statistical parameters of the refinement are: GOF (goodness of fit, $\left.X^{2}\right)=4.07 \%$, DW (Durbin-Watson statistics $)=1.49 \%$. The corresponding values associated with the quantitative phase analysis (whole angular range) are $4.34 \%$ for GOF and $1.70 \%$ for DW. Dominance of crandallite in this sample does not correspond to the EPMA observations. This may be due to (1) difference in original location of the sample, suggesting larger compositional spread within the profile, and/or (2) influence of admixing elements to reflection positions of at least some of the PGM representatives.

\section{DISCUSSION}

The bone replacement material and void-embedded aggregates of the Podłazie PGM are texturally different. The replacement matter seems to have its original bone structure pre- served at least to some extent; this includes both the fibrous structure and presence of Haversian canals. The aggregates residing outside the bone fragments seem to be of a secondary origin, as they fill veins and voids. The void-residing aggregates are usually rounded, but some of them have triangular outlines (see Fig. 3A). The above textural diversity suggest two-phase formation of the PGM: (1) replacement of the bone matter with relatively Ba-rich $\mathrm{PGM},(2)$ redeposition of slightly less Ba-rich but Ca-poor PGM in the surrounding sandstone matrix probably conciding with or followed by recrystallization of some of the PGM within both the bone remnants (as crandallite-rich crystals) and as Sr- and La-enriched zoned crystals in the sandstone. The triangular shape some of the type-I sandstone-embedded fine PGM aggregates suggests their formation at the expense of the type-II coarse crystals. The fine sandstone-embedded and intra-bone aggregates are chemically similar in terms of their $\mathrm{Ce}, \mathrm{Ca}$ and $\mathrm{F}$ content. However, the type I ones are enriched in Si but relatively depleted in $\mathrm{Ba}$. Thus, if the above-described redeposition process was true, it must have been complex and involved some silica-bearing solutions.

Interestingly, analyses of bone-related PGM by Coutinho et al. (1999) only rarely show fluorine (two of the total 11 analyses), but its observed content is $\sim 4$ times larger than the mean content in our material. Even slightly larger maximum value is given for gorceixite of Inner Mongolia coals by Dai et al. (2012), with mean being $1.21 \mathrm{wt} . \%$, although these values are of a semi-quantitative character. Although both crandallite analyses presented by Anthony et al. (2000) do not include F, those presented for goyazite have 1.93 to $2.80 \mathrm{wt}$ \% $\mathrm{F}$ (corresponding to crystals from the Oxford Mine in Maine, USA, and Alto Bernadino, Frei Martinho, Paraíba, Brazil, respectively). Gorceixite from Sydney Basin, Australia, has 2.3 wt.\% F, and florencite-(Ce) from Kangankunde Hill, Malawi - 1.6 wt.\% (Anthony et al., 2000). As opposed to the Australian one, gorceixite from Rapid Creek phosphate occurrence in Yukon, Canada, has only 0.03 wt. \% F on average. It is possible that our PGM's fluorine content reflects the original bioapatite $\mathrm{F}$ content. Although usually low in $\mathrm{F}$ (up to 1000 ppm at least for some archaeological materials), the original bone-forming carbonate-bearing hydroxylapatite may accumulate $\mathrm{F}$ during burial time (e.g., Reiche et al., 2002). Beside Ca, apatite group minerals are a known source of Sr, REE and F (Pasero et al., 2010). Sulphate- and silicate-rich members, although rare, are also known (e.g., Kruszewski, 2008).

The occurrence of PGM in detrital sands is mentioned by Frye (1981). Interestingly, Rasmussen (1996), who may be credited for a recognition of PGM as an important marine sink of reactive phosphorus, gave a short report on REE-rich PGM being abundant in Australian Archaean to Cretaceous sandstones. He suggested them to be of an early-diagenetic and authigenic origin and pointed to their possible formation in a sulphate reduction and methanogenesis zone. Rasmussen (1996) suggested two possible processes of the PGM formation: (1) release of $P$ and REE into sediment pore water, followed by bacterially-driven organic matter decomposition; or (2) dissolution/alteration of detrital grains.

Due to the confirmed occurrence of tuffite rocks in Podłazie we propose them as the most likely source of some of the elements constituting our PGM, especially $\mathrm{Al}$ and $\mathrm{Ba}$, with $\mathrm{Al}$ alternatively originating from weathering of claystones. However geochemical data on the Lower Devonian volcanogenic rocks of the Holy Cross Mountains is relatively limited. Tarnowska (1971) reported the $\mathrm{Al}_{2} \mathrm{O}_{3}$ content of the local tuffite rocks being in the $18-30$ wt. \% range. Although only measured qualitatively, $\mathrm{Ba}$ is the first trace element mentioned, while Sr is said to be observed only rarely. Muscovite present in the placoderm sand- 
stone, although not mentioned by Tarnowska (1971), may be derived from such rocks. It is, however, only an minor source of Ba in for our PGM. Triplehorn and Bohor (1983), who found goyazite in tuff beds of Colorado, suggested Sr being derived either from a volcanic (feldspar) or biogenic (shell-building aragonite) sink. So may be true for the Podłazie PGM, as the bone replacement matter is practically devoid of this element. Unfortunately no genetic remarks are provided in the paper of Coutinho et al. (1999) regarding analogous PGM related to sandstone-residing fossil bones from Brazil. On the other hand, these authors stated that the host rock for the bone remnants in their case is a clay-rich sandstone. It should be noted that Lower Devonian lamprophyre and diabase intrusions of the Holy Cross Mountains are associated with $\mathrm{Ba}$ and $\mathrm{Pb}$ mineralisation (Kowalczewski and Wróblewski, 1974) which may also be genetically important for our PGM.

The current paper is not the first one devoted to the PGM from the Holy Cross Mts. Migaszewski et al. (2007) described gorceixite and trace "florencite" and goyazite from a quarry in Podwiśniówka. These minerals occur in voids, cracks and fissures within Upper Cambrian clayey shales, quartzites, and tuffs. A similarity between the Podłazie and Podwiśniówka PGM is their enrichment in LREE. However, the association of the latter with pyrite and nacrite, and their occurrence in other lithological rock types suggests a slightly different mode of formation. To confirm or disclaim this and other genetic remarks placed, a laser-ablation inductively coupled plasma study of the REE distribution is needed. A trace-mode WDS microprobe analysing of REE contents for the Podłazie PGM, aimed to construct spider patterns, proved to be unsuccessful.

\section{CONCLUSIONS}

1. The local tuffites and claystones may be the source rocks for $\mathrm{Al}, \mathrm{Ba}$, and $\mathrm{Sr}$ for the PGM under study; $\mathrm{Pb}$ (and possibly $\mathrm{Ba}$ ) may likely be connected with the Lower Devonian lamprophyreand diabaze-hosted mineralisation.

2. The primary bone apatite is the most likely source of $\mathrm{Ca}$, $P$, and possibly $F$ for those PGM.

3. The current chemical characteristics of the PGM is a result of a complex, multi-stage process probably involving action of silica-bearing solutions.

Acknowledgements. This research was financed by the statute resources of the Institute of Geological Sciences, for years 2013 and 2017, apiece. The authors would like to thank L. Jeżak for her assistance by the microprobe analyses. Part of the analyses was conducted by P. Dzierżanowski, who specialized in the PGM and to whom this paper is dedicated. We are also thankful to the Reviewers: T. Cotterell and D. Atencio.

\section{REFERENCES}

Anthony, J.W., Bideaux, R.A., Bladh, K.W., Nichols, M.C., 2000 Handbook of Mineralogy, 4: Arsenates, Phosphates, Vanadates. Mineralogical Society of America, Chantilly, VA.

Bayliss, P., Kolitsch, U., Nickel, E.H., Pring, A., 2010. Alunite supergroup: recommended nomenclature. Mineralogical Magazine, 74: 919-927.

Bain, D.C., 1970. Plumbogummite-group minerals from Mull and Morvern. Mineralogical Magazine, 37: 934-938.

Bigham, J.M., Nordstrom, D.K., 2000. Iron and aluminum hydroxysulfates from acid sulfate waters. Reviews in Mineralogy and Geochemistry, 40: 351-403.

Burt, D.M., 1991. Vectors, components, and minerals. American Mineralogist, 76: 1033-1037.

Coutinho, J.M.V., Atencio, D., Coimbra, A.M., Fernandes, L.A., 1999. Gorceixite, a singular product of replacement in fossil bones from the Bauru Basin, Brazil. The Canadian Mineralogist, 37: 945-950.

Dai, S., Zou, J., Jiang, Y., Ward, C.R., Wang, X., Li, T., Xue, W., Liu., S., Tian, H., Sun, X., Zhou, D., 2012. Mineralogical and geochemical compositions of the Pennsylvanian coal in the Adaohai Mine, Daqingshan Coalfield, Inner Mongolia, China: modes of occurrence and origin of diaspore, gorceixite, and ammonian illite. International Journal of Coal Geology, 94: 250-270.

Dzikowski, T.J., Groat, L.A., Jambor, J.L., 2006. The symmetry and crystal structure of gorceixite, $\mathrm{BaAl}_{3}\left[\mathrm{PO}_{3}(\mathrm{O}, \mathrm{OH})\right]_{2}(\mathrm{OH})_{6}$, a member of the alunite supergroup. The Canadian Mineralogist, 44: 951-958

Frye, F., 1981. Alunite group, beudantite group, plumbogummite group. Encyclopedia of Earth Science, 7-8, doi 10.1007/0387-30720-6_4.

Klingelhöfer, G., Morris, R.V., Bernhardt, B., Schroder, C., Rodionov, D.S., de Souza, P.A., Yen, A., Gellert, R., Evlanov, E.N., Zubkov, B., Foh, J., Bonnes, U., Kankeleit, E., Gutlich, P., Ming, D.W., Renz, F., Wdowiak, T., Squyres, S.W., Arvidson, R.E., 2004. Jarosite and hematite at Meridiani
Planum from Opportunity's Mössbauer spectrometer. Science, 306: $1740-1745$.

Kolitsch, U., Pring, A., 2001. Crystal chemistry of the crandallite, beudantite and alunite groups: a review and evaluation of the suitability as storage materials for toxic metals. Journal of Mineralogical and Petrological Sciences, 96: 67-78.

Kowalski, W., Śmietańska, l., 1982. Gorceixite from a barite-fluorite deposit at Stanisławów (Kaczawskie Mts.). Mineralogia Polonica, 13: 3-20.

Kowalczewski, Z., Wróblewski, T., 1974. Problem of ore contents in sediments in the light of diastrophism and volcanism of the Świętokrzyskie Mts. (in Polish with English summary). Kwartalnik Geologiczny, 18 (3): 537-563.

Kruszewski, Ł., 2008. Apatite-ellestadite solid solution and associated minerals of metacarbonate slags from burning coal dump in Rydułtowy (Upper Silesia). Mineralogia - Special Papers, 32: 100.

Kruszewski, Ł., 2013. Supergene sulphate minerals from the burning coal mining dumps in the Upper Silesian Coal Basin, South Poland. International Journal of Coal Geology, 105: 91-109.

Migaszewski, Z.M., Starnawska, E., Gałuszka, A., 2007. Gorceixite from the Upper Cambrian Rocks of the Podwiśniówka Mine Pit, Holy Cross Mountains (South-Central Poland). Mineralogia Polonica, 38: 171-184.

Muszyński, M., Wyszomirski, P., 1982. Minerals of crandallite group in some tonsteins of the Lublin Coal Basin. Mineralogia Polonica, 13: 17-23.

Pasero, M., Kampf, A.R., Ferraris, C., Pekov, I.V., Rakovan, J., White, T.J., 2010. Nomenclature of the apatite supergroup minerals. European Journal of Mineralogy, 22: 163-179.

Rasmussen, B., 1996. Early-diagenetic REE-phosphate minerals (florencite, gorceixite, crandallite, and xenotime) in marine sediments: a major sink for oceanic phosphorus. American Journal of Science, 296: 601-632. 
Reiche, I., Vignaud, C., Favre-Quattropani, L., Menu, M., 2002. Fluorine analysis in biogenic and geological apatite by analytical Transmission Electron Microscopy and Nuclear Reaction Analysis. Journal of Trace Microprobe Techniques, 20: 211-231.

Rietveld, H.M., 1967. Line profiles of neutron powder-diffraction peaks for structure refinement. Acta Crystallographica, 22: 151-152.

Szrek, P., Niedźwiedzki, G., Dec, M., 2014. Storm origin of bone-bearing beds in the Lower Devonian plakoderm sandstone from Podłazie Hill (Holy Cross Mountains, central Poland). Geological Quarterly, 58 (4): 795-806.

Tarnowska, M., 1971. Lower Devonian polymict and tufaceous rocks in the Kielce Region of the Świętokrzyskie Mountains (in Polish with English summary). Kwartalnik Geologiczny, 15 (3): 569-596.

Triplehorn, D.M., Bohor, B.F., 1983. Goyazite in kaolinitic altered tuff beds of Cretaceous age near Denver, Colorado. Clays and Clay Minerals, 31: 299-304. 